ISBN 978-93-84468-75-0

International Research Conference on Literature, Humanities and Sociology (RCLHS-2016)

Oct.11-12, 2016 at Dubai (UAE)

\title{
Attitudes towards Religion and Religious Practices among Youth: A Qualitative study
}

\author{
Thushara Mariam Thomas ${ }^{1}$ and Dr. Shailaja Shastri ${ }^{2}$ \\ ${ }^{1}$ Student, Dept. Of Psychology, Jain University \\ ${ }^{2}$ Head of Dept. Of Psychology, Jain University
}

\begin{abstract}
The current study titled- 'Attitudes towards Religion and Religious Practices among Youth: A Qualitative study' aimed to understand the various religious beliefs held by the youngsters and relevance of religion among them. The study was conducted in the city of Bangalore among youngsters between the ages of 18 and 24. A semi-structured interview and a few one statement only rating scales were embedded in the interview to get more specific responses. The study was conducted on 18 individuals from three main religions- Hinduism, Christianity and Islam, from Science, Arts and Commerce domains who were selected through purposive sampling. Thematic and Content Analysis was conducted to capture the various themes that emerged from the study. Results indicated that religion is relevant among the youth. Most of the individuals preferred to adopt the status of 'free-thinker'. Media did not have a strong impact on religious beliefs. Religious beliefs did not influence voting patterns. An overarching opinion about religion was that religion should be more open-minded and liberal.
\end{abstract}

Keywords: Religion, Religious Attitudes, Youth

\section{Introduction}

Religion can be considered as one of the most important social institutions, which belongs to almost all known societies in one form of the other. Societies have many forms or types of beliefs that can be grouped under the word religion. These beliefs may vary from culture to culture or society to society. Religion forms an intrinsic part of our society. The idea of religion can be interpreted differently by different people. Religion is an important aspect of everyone's life, which can take on different meaning as one progresses through life.

The current study is aimed at understanding the various beliefs and perceptions the youth of Bangalore hold towards religion and related practices. Youth form an important aspect of human generation as they would be taking the human race forward. Their ideas and notions would be carried forward to the coming generations. Therefore, studying their opinions would give insight into what aspects, thoughts, perceptions and opinions about religion would be passed on. Religion being such a powerful constituent of people's lives, influences various domains. It is also important to also understand the areas that religion influences and how religion and religious ideologies form the basis of various decisions that are taken in our lives.

Sociology studies man within his social relationships whereas psychology studies the mind and emotions of men for various objects. Religion is an important entity of man's social relationship along with mind and emotions which are interdependent. Therefore, sociology and psychology of religion must intertwine. Psychology of religion is interested in the beliefs and actions associated with religion. It attempts to study the various beliefs that man holds, the processes and intensity of it and its expressions and reasons. It also takes into consideration the impact of these beliefs on the individual and his society. This highlights the need to study religion from a psychological viewpoint. 
Religion is a very sensitive topic in India. In addition to being a very sensitive it is one of the most influential factors in an individual's life. One's religion can have a widespread impact on a person's life. It can have an influence on major life decisions such as education, marriage and the like. There is a need to understand the level of impact religion has on the present generation to determine the aspects over which it has an impact and its relevance among today's generation. There is a need to find out more about how relevant religion actually is among the youth.

India has recently seen many circumstances of religious intolerance. People from all parts of the country and all walks of life have been directly or indirectly been affected by such instances. Though those responsible for such instances are few, it is of utmost relevance. Therefore it is important to understand the relevance of such happenings from the point of view of our youngsters who are the future of our country and who would be playing an important part in the functioning of our country in the future years. It is also necessary to understand the kinds of discrimination that our youngsters may have gone through or their opinions on such instances. This would also highlight the attitudes that they hold towards other religion.

18-24 is an age range where individuals are influenced by various factors. It is a period of life when certain fundamental beliefs may be formed. Religious orientation being one of the fundamental aspects of our lives, the attitudes towards it can be formed during this age range along with attitudes towards certain other aspects of life. These beliefs can be lifelong as well. Most of the individuals who belong to this age range are in a phase of life where most of their time is spent in their educational institutions and among their friends. These aspects can influence their thought processes as well. It is also the age where there is a lot of interaction between many individuals who can influence others. Therefore, it is important to understand the extent to which these factors can be an influence on the thought patterns of these individuals.

\section{Method}

The study was conducted in Bangalore, a tier 1 city. The sample size consisted of 18 individuals between 18 and 24 years of age with 6 individuals from each branch of Arts, Commerce and Science. 1 girl and 1 boy were selected from all the three religions- Hinduism, Islam and Christianity. The current study employed a purposive sampling technique as the subjects for the study were selected on the basis of certain characteristics that were the focus of the study.

A semi-structured interview was conducted where the questions were developed by the researcher. The questions were framed to obtain insight into the attitudes that the youth held towards religion and religious practices, the relevance of religion and religious practices among the youth.

Thematic and Content Analysis was used to analyze the data obtained.

\section{Qualitative Analysis}

\subsection{Religious Beliefs}

Religious beliefs form an important part of one's religious identity. Therefore, the participants were asked to rate their religious beliefs and the extent to which they believed that God influenced the events that took place in their life on a scale from 1 to 10, with 1 being very low and 10 being extreme.

It was seen that the group on a whole had an average level of religious beliefs. Christians were seen to have a comparatively lower level of religious beliefs while Muslims were seen to be more religious. It was also seen that the level of belief that the group had on the influence of God in their life was high. Muslims and Hindus had a greater belief on God's impact on their lives compared to Christians.

\section{Relevance of religion during decision making}

The relevance of religion on decision making was assessed by asking the participants to what extent they thought that their religious beliefs had an impact on their decisions. 66.7\% of the Muslims who took part in the study reported that they took all their decisions on the basis of their religion. Only one of the Christian 
respondent stated that the decisions the individual made was completely based on religion. Whereas, $50 \%$ of the population of Hindus and Christians stated that their decisions were based on the situation, rather than on their religious beliefs. $33.33 \%$ have stated that their religious beliefs has no impact on their decisions.

The aim of this question was to understand the level of religious beliefs present among the youth. A strong religious base would transform into other aspects of an individual's life. One such aspect is decision making. A person who has a strong religious foundation may tend to take their decisions on the basis of their religion. Followers of the religion of Islam have been found to be more religious than the followers of other religion. They possessed strict prescriptions and practices of religion. They tended to attribute important decisions taken in their life to religion. And their intensity of religious beliefs was found to be high. (Joshi, Deb and Joy, 2014). The current study also found similar results. Among the members of the sample selected, it was found that Muslims were higher on their level of religious beliefs as $66.7 \%$ of those who stated that they base their decisions on religion were Muslims.

\section{Raising children}

The opinions on how children would be raised was assessed by asking the respondents how they would like to raise their children, specific to religious beliefs. It was seen that $44.4 \%$ of the individuals stated they want to bring their children up in a not-too-religious manner. Nearly $28 \%$ of the individuals who were interviewed stated that they wanted to bring their child up in a democratic manner. The rest of the individuals preferred to bring their children up strictly on the basis of religion. Out of those who stated that they wanted to bring their children up in a religious way, it was $60 \%$ of the Muslims who were interviewed who preferred to bring their child up on a religious basis. $40 \%$ of the Hindus and Christians preferred to bring their children up in a not too religious way.

The data shows diverse opinions on how the individuals would like to bring their children up. They have stated how they would like to bring their children up in a religious way or give them freedom or ensure that too much of attention is not given to religion. However this question is a hypothetical one as it is a future oriented question. Some of the respondents have taken a middle path on this question. It may also show that some individuals have not actually given much thought as to how they may bring their children up. However, the question can help get an idea regarding how these individuals would like to carry forward their religion to their children and future generations.

\section{Influence of media}

The impact of media on religious beliefs was assessed by asking the respondents if they felt that media had any impact on their religious beliefs. And if it did have an influence how and in what manner did they feel media had an impact on their religious beliefs. The responses of the subjects were categorized on the basis of whether they stated that it had an influence, if it had influence sometimes and if it had no impact at all. It was seen that out of the total sample, $55.5 \%$ of the individuals stated that media does not have an impact on their religious beliefs. $27.8 \%$ of the sample believed that media can sometimes have an impact on their religious beliefs and only $16.7 \%$ believed that media influences their religious beliefs. $66.7 \%$ of the Hindus and Christians believed that media does not have an influence while only 33.3\% Muslims believed that media does have an impact. An equal number of Hindus, Christians and Muslims stated that media influences their religious beliefs. Among those who have stated that media sometimes has an influence, it is $60 \%$ of the Muslims who believed that media can sometimes influence their religious beliefs while only $20 \%$ of Hindus and Christians believed that media can sometimes have an influence on their religious beliefs.

Hirschkind (2011) in his article talks about how the sudden boom in media has an immense impact on several aspects of our life, out of which religion and religious beliefs is an important one. Anthropologists who have been working within various religious contexts have spoken about how followers of different religion have brought about certain changes in their belief systems and traditions as a result of this influence. An increase in the use of media by those who practice religious traditions has associated with the increase in the prominence of religion as a social and a political force. Some people have termed this as the 'the return of religion'. 
The results found in the study shows that there is a diverse opinion regarding the influence of media. While some respondents are clear about the level of influence of media, there are others who maybe influenced by media but not really aware of how it does. Media plays a significant part in the lives of youngsters. But they also have their freedom to choose what they view. This can be an important factor to understand the impact of media on their religious beliefs. Youngsters pick and choose from different religions, rituals and conceptions and create their own from these. Media can be an important source of information for the creation of their unique belief system. (Stout, 2006).

\subsection{Relevance of religion}

The subjects were asked their opinions about how relevant religion is among the youngsters today. This question was of utmost importance as it helped understand the main focus of the study. The responses were categorized based on whether religion was relevant or not relevant.

The current study aims to understand how relevant religion is among the youth. The purpose of this question was to get direct opinions of people regarding the relevance of religion among today's youngsters. It was seen that $89 \%$ of the participants stated that the relevance of religion is coming down. Another interesting attribution made by one of the respondents is that the relevance is coming down due to inter-religion marriages. Only one subject stated that religion is actually important.

Some of the reasons quoted for the reduction in the level of religious beliefs is the modernization of our society. The study conducted by Joshi, Deb and Joy (2014) noted that many believed that God is a kind of supreme energy, every individual has a soul which is connected with supernatural. It was found that a large number of individuals were sceptic in their belief in religion, most were not involved in constant praying. Muslim youth were more religious than others.

Durkheim in his functional theory of religion states that the relevance for religion or the influence of religion on people would decrease as modernization of society takes place. It would be replaced by scientific thinking. However, from the previous answers, it can be seen that for most of the individuals religion has a good basis. But the way the individuals accept various aspects associated with religion varies. They are not ready to blindly follow everything. They think, pick and choose and then follow. Religion has also been found to be impacted by globalization which is bringing the world closer. Globalization has been believed to bring about transformation in traditional religions and belief systems. (Khaled, 2007). Therefore to some extent, the reasons for changes in thoughts and belief systems of the youngsters can be attributed to globalization.

\section{Influence of religion on voting patterns}

An important aspect where religion can influence our thinking patterns is our voting choice. The participants were asked about their opinion on what kind of influence their religious beliefs had on their voting patterns.

"I think its fair to say that there's good reason to keep God out of politics", Chopra (2011).

The struggle between religion and politics has been described as a struggle between the behaviour of humans and aspirations of humans. Religion and politics are two separate entities which are not really meant to be mixed up. But in a country like India, there is a lot influence of religion in the political system. Both religion and politics co-exist (Roy, 2013). Various political parties in India based their ideology on the concept of 'Hindutva' which they claim have national and patriotic association and is not just equal to Hinduism (Mahmood, 2006). These views have also been intensified by some of the religious heads.

It was seen that $83.3 \%$ of the individuals stated that their religious beliefs did not have any influence on their voting patterns. Most of them stated that they are able to distinguish between religion and politics. Their main aim is to vote for someone who would bring about development in their land, rather than vote for a candidate who may belong to their own religion or community. Out of those who stated that their religious beliefs has an impact on their voting patterns, $66.67 \%$ are Christians. The reason stated by these individuals is that they 
consider BJP, our ruling party at the centre, to be anti- Christians and pro-Hindus. Therefore, they feel a little insecure about it.

Therefore it can be seen that the youngsters today do not rely on religion completely when it comes to choosing their political leaders. They would prefer to think and then take a decision based on the qualities of a political representative rather than which religion he or she belonged to.

\section{Opinion on religious free-thinking}

The subjects were asked about their views on accepting the title of free-thinker. They were asked to imagine a situation in India where they could choose being a free-thinker instead of being a part of their specific religion.

Religious free-thinking is an upcoming idea. There are countries such as Singapore where an individual is allowed to state their religion as a 'free-thinker'. A free-thinker is an individual who believes in God but does not follow the religious division into various religions. They believe in following all religions. There are many online groups that have come up in India where people discuss the concept of free-thinking. Such groups on Facebook have been attacked by Hindu and Islamist fundamentalists and forced to close down. (The Hindu, 2013).

The aim of this question in the interview was to obtain different perspectives regarding this concept in an Indian scenario. $61 \%$ of the participants stated that they would not mind being known as a free thinker and someone who does not belong to any religion. While 39\% have stated that they would prefer to be with their religion and not accept the idea of being a free-thinker. One of the respondents has given a different perspective to this idea and stated how it would become a religion and there would be disciples added. Another individual has stated that if we have the whole concept of free thinker, the level of discrimination faced would reduce. The number of atrocities committed in the name of religion would come down. But the tight knit of religion in a country like India can be seen in the $39 \%$ of individuals who prefer to remain with their religion.

\section{Questioning religious practices}

Every religion has a whole set of practices laid down that people follow. The subjects were asked about their opinion on whether we should question certain religious practices that we consider not important or redundant or be quiet about it.

There is a need to understand if it is a right practice to ask questions regarding this aspect. Is it right that we question existing religious practices so that we get a clarity or bring about changes in the practices in a more sensible manner? Individuals who took part in the study have mutually stated that we have to question whatever religious practices are there; especially if they want to know the scientific reason behind following such practices.

Total adherence to any aspect comes when one is able to fully understand the meaning of something and appreciate it. The same applies to religious practices as well. It is only when people ask doubts and get their doubts clarified, will they follow what is stated. It is also important to ask questions as it helps prevent transmission of wrong information. Religion is an important part of the existence of human beings. Therefore, if it has to be transferred to others or future generations in a correct way, one should get their doubts clarified. For this to take place, one should ask questions and distinguish between right and wrong religious beliefs. It highlights the importance of asking and then building our knowledge based on the right beliefs which is formed after repeated questioning and developing the right knowledge.

\section{Acceptance of religious rules}

Every religion has a certain set of rules and practices laid down. The extent to which these rules are followed determine the attitudes towards religion. There are some individuals who claim that they belong to a particular religion. Individuals either follow all the rules laid down by their religion or they choose which ever they think is important and leave out the rest. Hence, it is important to know about the opinions of our youngsters as to what they prefer to do. It also shows to what extent they are ready to accept the rules laid down and also if the rules are accepted without questioning or is there full acceptance. 
$72 \%$ of the individuals stated that it is better for an individual to follow what they personally feel is right and not adhere to all the rules laid down. However, around $28 \%$ feel there is a need to follow all the rules and not choose what one likes.

\section{Implications and Conclusion}

The purpose of this study was to understand the level of religious beliefs among the youth and its relevance among them. Though most of the participants stated that the relevance of religion is declining, most of the participants have stated that they are religious. This shows that religion still remains an important entity among the youth of Bangalore. Further research can be conducted with a larger sample and including other religions. Research design that include case studies or individual narratives could enhance the quality of inferences.

\section{Acknowledgements}

I would like to express my gratitude to my guide- Dr. Shailaja Shastri whose knowledge and support helped in the research process. I would like to thank all my participants who agreed willingly to be a part of my study. I would also like to thank my teachers for their constant support and my institution- Jain University, for the opportunity. I also extend my gratitude towards my friend Snigdha Ubba for her help. Last, but not the least, I also thank my family and friends who helped throughout the research.

\section{References}

[1] Argyle, M., \& Beit-Hallahmi, B. (1975). The Social Psychology of Religion. Boston: Routledge \& Kegan Paul Ltd.

[2] Chopra, D. (2011, June 24). Religion and politics. Retrieved April 28, 2016 from: http://timesofindia.indiatimes.com/Religion-and-politics/articleshow/8142045.cms

[3] Hirschkind, C. (2011). Media, Mediation, Religion. Retrieved April 29, 2016 from: https://www.academia.edu/15830078/Media_mediation_religion

[4] Jackson, M.J. (1974). The psychology of religion. In The Sociology of Religion (pp: 66-69). London: Willmer Brothers Ltd.

[5] Joshi, T., Deb, R., \& Joy, R. (2014). An Anthropological Study towards the Religious Beliefs amongst the Youths in India. Double Blind Peer Reviewed International Research Journal, 14 (2), 20-28.

[6] Khaled, M. (2007, June). Globalization of Religion. Retrieved April 28, 2016 from: http://www.ihmsaw.org/resourcefiles/1260067215.pdf

[7] Lessa, W.A., \& Vogt, E.Z (1972). Reader in Comparative Religion- An Anthropological Approach (3rd ed.). United States of America: Harper and Row Publishers Inc.

[8] Mahmood, T. (2006). Religion, Law and Judiciary in Modern India. Brigham Young University Law Review, 3, 755 775.

[9] Roy, A. (2013, September 10). Importance of Religion in Politics. Retrieved April 29, 2016 from: http://www.importantindia.com/2439/importance-of-religion-in-politics/

[10] Stout, D.A. (2006). Encyclopedia of Religion, Communication, and Media. NY: Berkshire Publishing Group.

[11] The Hindu (2013, June 12). Radical users hound free thinkers on FB. Retrieved January 04, 2016: http://www.thehindu.com/news/cities/Kochi/radical-users-hound-free-thinkers-on-fb/article4804734.ece 